\title{
On-board $\mathrm{H}_{2}$ generation by catalytic dehydrogenation of hydrocarbon mixtures or fuels
}

\author{
Carlo Lucarelli ${ }^{a}$, Stefania Albonetti ${ }^{a}$, Angelo Vaccari ${ }^{a}, *$, Carlo Resini ${ }^{\mathrm{b}}$, Gilles Taillades ${ }^{\mathrm{b}}$, Jacques Roziere ${ }^{\mathrm{b}}$, \\ Kan-Ern Liew ${ }^{c}$, Alexander Ohnesorge ${ }^{c}$, Christian Wolff ${ }^{c}$, Ilenia Gabellini ${ }^{\mathrm{d}}$, David Wails ${ }^{\mathrm{d}}$ \\ a Dip. di Chimica Industriale e dei Materiali, Alma Mater Studiorum - University of Bologna, Via Risorgimento 4, 40136 Bologna, Italy \\ b ICGM - Aggregates, Interfaces, Materials for Energy, CNRS-University Montpellier 2, France \\ ${ }^{\mathrm{c}}$ EADS Deutschland GmbH, Willy-Messerschmitt Strasse, D-81663 Munich, Germany \\ d Johnson Matthey Technology Centre, Sonning Common, Reading, Berkshire RG4 9NH, United Kingdom
}

\section{A R T I C L E I N F O}

\section{Article history:}

Received 14 October 2010

Received in revised form 9 February 2011

Accepted 28 February 2011

Available online 13 April 2011

\section{Keywords:}

Hydrogen production

Dehydogenation

$\mathrm{Pt} /$ Sn catalysts

Kerosene surrogate

\begin{abstract}
A B S T R A C T
The partial dehydrogenation (PDh) of hydrocarbon blends may be a suitable way to produce $\mathrm{H}_{2}$ on-board of automotives or airplanes to feed fuel cells and produce electric power, avoiding storage problems. In this work very interesting data have been collected using Jet A-1 surrogate and $\mathrm{Pt}-\mathrm{Sn} / \gamma-\mathrm{Al}_{2} \mathrm{O}_{3}$ catalysts, operating at $450^{\circ} \mathrm{C}$ and feeding the vaporised hydrocarbon blend without any carrier gas. The use of $\mathrm{Pt} / \mathrm{Sn}$ catalyst with $1: 1(\mathrm{w} / \mathrm{w})$ ratio leads to the best compromise between activity and stability with timeon-stream, due to the formation of Pt-rich alloys. Nevertheless, all studied catalysts exhibited limited thio-tolerance. In optimized reaction conditions, $\mathrm{H}_{2}$ productivity of $3000 \mathrm{NL} / \mathrm{kg}_{\text {cat }} / \mathrm{h}$, sufficient to produce $3 \mathrm{~kW}$ of electric power, considering purification steps and a fuel efficiency of $50 \%$, was obtained.
\end{abstract}

(C) 2011 Elsevier B.V. All rights reserved.

\section{Introduction}

To avoid problems of storage and transport, on-board efficient $\mathrm{H}_{2}$ production technologies are drawing more and more attention [1-5]. The dehydrogenation of cyclic hydrocarbons with high hydrogen content, known also as "chemical hydrides" or "organic hydrides" is a promising method for storing and transporting hydrogen [4,6-8]. Moreover, the idea to use fuels like diesel or kerosene cuts as a $\mathrm{H}_{2}$ source is attracting increasing interest $[9,10]$, with the goal to further upgrade an already valuable energy carrier (the fossil fuel) by extracting another energy carrier $\left(\mathrm{H}_{2}\right)$.

The lack of oxygen in hydrocarbon fuels make them suitable for partial dehydrogenation products which are liquid phase dehydrogenated hydrocarbons and gas phase $\mathrm{H}_{2}$, easy to separate. Therefore, because of the absence of carbon oxides, the gas stream may be directly fed without any further purification to on-board PEM fuel cells to supply electric energy to auxiliary systems on heavy duty transportation systems, such as ships and aircraft. The liquid mixture, composed of partially dehydrogenated hydrocarbons, still maintains its original fuel properties making hydrocarbon fuels appealing $\mathrm{H}_{2}$-storage media. Although several different metal-supported catalysts have been investigated

\footnotetext{
* Corresponding author. Tel.: +39 051 2093683; fax: +39 0512093679. E-mail address: angelo.vaccari@unibo.it (A. Vaccari).
}

for cycloalkane dehydrogenation, $\mathrm{Ni}$ and Pt are among the most used metals $[4,6,10-14]$ : $\mathrm{Ni}$ is cheaper than Pt, but less selective in dehydrogenation reactions and favours cracking reactions at high temperatures. The support also plays a key role and different types have been investigated, like alumina $[6,10,15]$, alumina-sulfated zirconia [10], silica [17], activated carbon [11,13,16], carbon nanofibres $[8,18,19]$ or nanotubes [14].

The set-up of the catalyst for hydrocarbon fuel dehydrogenation to produce $\mathrm{H}_{2}$ without compromising the original fuel properties is a key-point; the tailored catalyst has to favour dehydrogenation or reforming (isomerisation, cyclisation, aromatisation) reactions, avoiding polymerisation or cracking reactions, responsible for coke deposition and catalyst deactivation. The open literature is rather poor on this topic, and it appear that only Wang et al. have studied this subject [10]. The aim of the work described below was the preparation and characterisation of alumina supported Pt-Sn catalysts for partial dehydrogenation of Jet A-1 surrogate fuel to produce $\mathrm{H}_{2}$ to feed on-board PEM fuel cells.

\section{Experimental}

\subsection{Catalyst preparation}

Three catalysts, $1 \mathrm{wt} . \% \mathrm{Pt} / \gamma-\mathrm{Al}_{2} \mathrm{O}_{3}$, and $1 \mathrm{wt} . \% \mathrm{Pt}-1 \mathrm{wt} . \% \mathrm{Sn} / \gamma$ $\mathrm{Al}_{2} \mathrm{O}_{3}$ and $1 \mathrm{wt} . \% \mathrm{Pt}-3 \mathrm{wt} . \% \mathrm{Sn} / \gamma-\mathrm{Al}_{2} \mathrm{O}_{3}$, hereinafter called Cat1, Cat2 and Cat3 respectively (Table 1 ), have been prepared by two 
Table 1

Composition and surface characterisation data for fresh and spent catalysts.

\begin{tabular}{|c|c|c|c|c|c|}
\hline Sample & Pt (wt.\%) & Sn (wt.\%) & BET surface area $\left(\right.$ in $\left.^{2} \mathrm{~g}\right)$ & BJH pore volume $\left(\mathrm{cm}^{3} / \mathrm{g}\right)$ & BJH pore width $(\AA)$ \\
\hline Cat 1 fresh & 1 & - & 138 & 0.432 & 91 \\
\hline Cat 2 fresh & 1 & 1 & 135 & 0.419 & 90 \\
\hline Cnt 3 fresh & 1 & 3 & 136 & 0.422 & 88 \\
\hline Cat l spent & 1 & - & 128 & 0.389 & 94 \\
\hline Cat 2 spent & 1 & 1 & 125 & 0.366 & 92 \\
\hline Cat 3 spent & 1 & 3 & 126 & 0.372 & 93 \\
\hline
\end{tabular}

successive incipient wetness impregnations. The $\gamma-\mathrm{Al}_{2} \mathrm{O}_{3}$ support $\left(\mathrm{Al}_{2} \mathrm{O}_{3}-\mathrm{SCF} 140\right.$ Sasol, BET surface area $\left.=140 \mathrm{~m}^{2} / \mathrm{g}\right)$ was at first impregnated by a solution of $\mathrm{H}_{2} \mathrm{PtCl}_{6}$ (Johnson Matthey) and dried under vacuum in rotavapor; then it was further heated at $110^{\circ} \mathrm{C}$ for $2 \mathrm{~h}$ and calcined at $500^{\circ} \mathrm{C}\left(10^{\circ} \mathrm{C} / \mathrm{min}\right)$ for $8 \mathrm{~h}$. A second impregnation was performed using a solution of $\mathrm{SnCl}_{2} \cdot \mathrm{H}_{2} \mathrm{O}$ (Alfa Aesar) in the appropriate amount for the desired $\mathrm{Pt} / \mathrm{Sn}$ ratio, the product was dried in rotary evaporator, then heated at $110^{\circ} \mathrm{C}$ for $2 \mathrm{~h}$ and calcined at $500^{\circ} \mathrm{C}\left(10^{\circ} \mathrm{C} / \mathrm{min}\right)$ for $8 \mathrm{~h}$.

\subsection{Catalyst characterisation}

Specific surface area determinations were performed in a Micromeritics ASAP 2020 instrument. The samples were previously outgassed at $120^{\circ} \mathrm{C}$ until a pressure of 0.04 bar was reached and maintained for $30 \mathrm{~min}$. Calcined solids were heated at $150^{\circ} \mathrm{C}$ until 0.04 bar was reached, then kept $30 \mathrm{~min}$ at this temperature and finally heated up to $250^{\circ} \mathrm{C}$ and maintained for $30 \mathrm{~min}$. X-ray diffraction powder (XRDP) patterns were recorded on a Philips PW 1050/81 goniometer, equipped with a PW 1710 unit, using $\mathrm{Cu}-\mathrm{K} \alpha$ radiation $(\lambda=0.15418 \mathrm{~nm}, 40 \mathrm{~kW}, 25 \mathrm{~mA})$. Raman analysis were performed using a Renishaw 1000 instrument equipped with a Leica DMLM microscope, laser source Diod $(780 \mathrm{~nm})$ on both fresh and spent samples, in the last case the samples were pretreated under vacuum at $350{ }^{\circ} \mathrm{C}$ into desorb surrogate molecule adsorbed. Thermal-programmed-oxidation (TPO) and reduction (TPR) characterisations were performed using a Thermoquest TPDRO1100 instrument. The fresh and spent samples were loaded in a quartz reactor and pre-treated in nitrogen at $150^{\circ} \mathrm{C}$ for $30 \mathrm{~min}$ to eliminate weakly adsorbed species. After cooling at room temperature, $\mathrm{N}_{2}$ was replaced by the analysing gas $\left(5 \% \mathrm{H}_{2}\right.$ in argon for TPR tests, $5 \%$ $\mathrm{O}_{2}$ in $\mathrm{He}$ for TPO), and the temperature was increased up to $500{ }^{\circ} \mathrm{C}$ $\left(10^{\circ} \mathrm{C} / \mathrm{min}\right)$ for $\mathrm{H}_{2}-\mathrm{TPR}$ and up to $600^{\circ} \mathrm{C}\left(10^{\circ} \mathrm{C} / \mathrm{min}\right)$ for $\mathrm{O}_{2}-\mathrm{TPO}$ and maintained for $20 \mathrm{~min}$.

\subsection{Catalytic activity tests}

Catalytic tests were performed in a continuous tubular steel reactor (length $530 \mathrm{~mm}$; internal diameter $8 \mathrm{~mm}$ ) placed in a programmable furnace. Catalytic bed temperature was controlled by a thermocouple sliding internally. $3 \mathrm{~cm}^{3}$ of catalyst (14/20 mesh) were loaded in the reactor and activated at $350{ }^{\circ} \mathrm{C}$ for $2 \mathrm{~h}$ under a $200 \mathrm{~mL}$ flow of $\mathrm{H}_{2} / \mathrm{N}_{2}(40 / 60, \mathrm{v} / \mathrm{v})$. Liquid reactants (JetA1 surrogate or JA1-S) were vaporised before mixing with preheated diluent $\mathrm{N}_{2}$, if applied. The JA1-S blend used in the present tests includes five components in the following volume percentages: dodecane $65 \%$; methyl-cyclohexane $14 \%$; ter-butylbenzene $10 \%$; decalin $6 \%$; tetralin 5\%; $50 \mathrm{ppm}$ of sulfur (when used) were introduced feeding 3-methylthiophen (all reactants were from Aldrich, purity grade $>98 \%$, and used without any further purification). Tests were performed in the $350-550{ }^{\circ} \mathrm{C}$ range, varying the feed composition from 10 to $100 \%$ of JA1-S in $\mathrm{N}_{2}$ : Finally also pure JA1-S containing $50 \mathrm{ppm}$ of $\mathrm{S}$ was fed. The contact time and pressure were $2 \mathrm{~s}$ and $0.5 \mathrm{MPa}$ in all tests. Effluent gases were analysed on-line by a Agilent $7890 \mathrm{~A}$ gas-chromatograph equipped with a TCD, while the liquid products were analysed off line by the same GC using a FID detector.

\section{Results and discussion}

\subsection{Catalyst characterization}

Fig. 1A and B shows the XRDP patterns for Cat1-3, fresh and spent catalysts, i.e. samples downloaded after reaction in the following conditions: $T=450{ }^{\circ} \mathrm{C}$; feed composition (93\% surrogate-7\% $\mathrm{H} 2$ ); contac time $=2 \mathrm{~s} ; P=0.5 \mathrm{MPa}$; time on stream $=5 \mathrm{~h}$. All the fresh catalysts (Fig. 1A) show the presence of traces of crystalline $\mathrm{Pt}^{0}$ cubic phase on the support (mixture of $\gamma$ and $\delta-\mathrm{Al}_{2} \mathrm{O}_{3}$ ), while the Sn-containing samples (Cat2 and Cat3) also provide evidence for the presence of traces of various alloys of Pt and Sn, in particular a Pt-rich alloy, $\mathrm{Pt}_{9} \mathrm{Sn}$-like. According to Lieske and Völter [20], the formation of Pt-Sn alloys on $\gamma-\mathrm{Al}_{2} \mathrm{O}_{3}$ depends on the Snconcentration, because the metallic Pt catalyses the reduction of $\mathrm{Sn}(\mathrm{II})$ to $\mathrm{Sn}(0)$ and stabilises it as an alloy.

The catalysts after reaction (Fig. 1B) show a significant evolution of the active phase, depending on the Sn-content. Exposure to a reducing atmosphere, at relatively high pressure and temperature, leads to the further formation of $\mathrm{Sn}^{0}$, which is stabilised in different Pt/Sn alloys. In particular, while the spent $\mathrm{Sn}$-free sample (Cat1) displays an XRDP pattern comparable to that of the fresh sample, significant differences are visible on increasing the Sncontent. The spent sample containing the higher Sn-amount (Cat3) shows the further formation of Sn-rich alloys, probably hexagonal Pt-Sn- and/or cubic $\mathrm{Sn}-\mathrm{Pt}_{3}$-like alloys. The formation of these phases causes the decrease of peak intensities relative to $\mathrm{Pt}^{0}$. For all samples a little amount of crystalline graphite is also detectable, formed during the reaction tests.
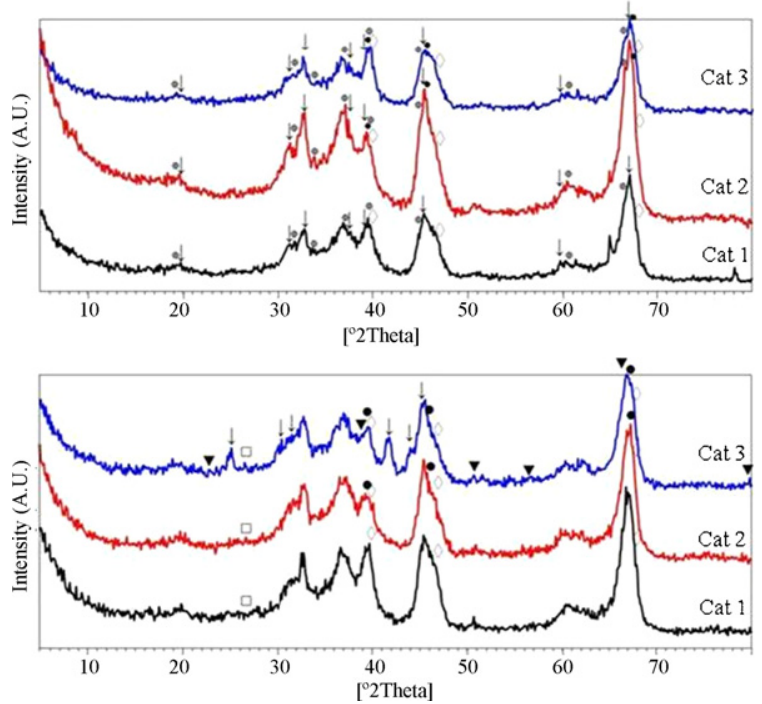

Fig. 1. (A) XRD powder patterns for fresh catalysts; phase identification: $\gamma-\mathrm{Al}_{2} \mathrm{O}_{3}$ 00-050-0741 ( ); $\delta-\mathrm{Al}_{2} \mathrm{O}_{3}$ 00-046-1131 ( $\left.\downarrow\right)$; Pt 00-001-1190( $\left.\diamond\right) ; \mathrm{Pt}_{9} \mathrm{Sn}$ 03-065-9538 (๑). (B) XRD powder patterns for spent catalysts; phase identification: graphite ( $\square$ );

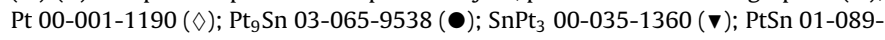
$2056(\downarrow)$. 

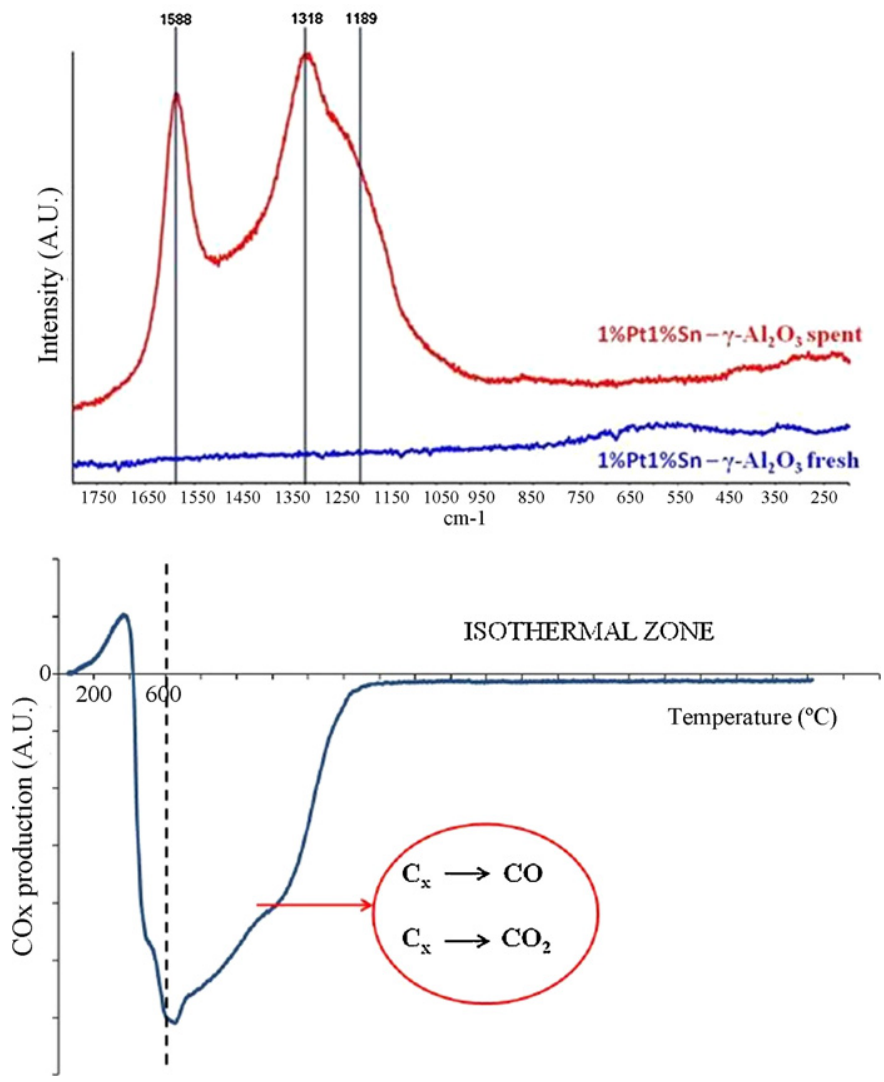

Fig. 2. (A) Raman spectrum of Cat2 fresh and spent, respectively. (B) TPO of spent Cat2 $\left(C_{\mathrm{x}}=\right.$ surface tar $)$.

The surface area for fresh samples (Table 1 ) is about $135 \mathrm{~m}^{2} / \mathrm{g}$ and volume and pore diameter are similar for samples (about $0.420 \mathrm{~mL}$ and $90 \AA$, respectively), indicating that the different Sncontent does not affect the surface properties. The catalysts after reaction show a slight decrease $(10 \% \mathrm{ca})$ of surface area and pore volume, mainly due to coke deposition. The presence of coke on the catalyst surface is confirmed by Raman spectra (Fig. 2A) that show two broad bands centered at 1588 and $1320 \mathrm{~cm}^{-1}$, attributable to crystalline and disordered graphite [21], respectively. The TPO thermograms show for all samples (Fig. 2B) two negative peaks at about 500 and $600{ }^{\circ} \mathrm{C}$, due to the combustion of adsorbed coke, suggesting that the catalysts may be easy regenerated by calcination. The $\mathrm{H}_{2}$-TPR thermograms for fresh Cat1 and Cat3 (Fig. 3) show for the former catalyst, containing only $\mathrm{Pt}$ as active phase, the presence

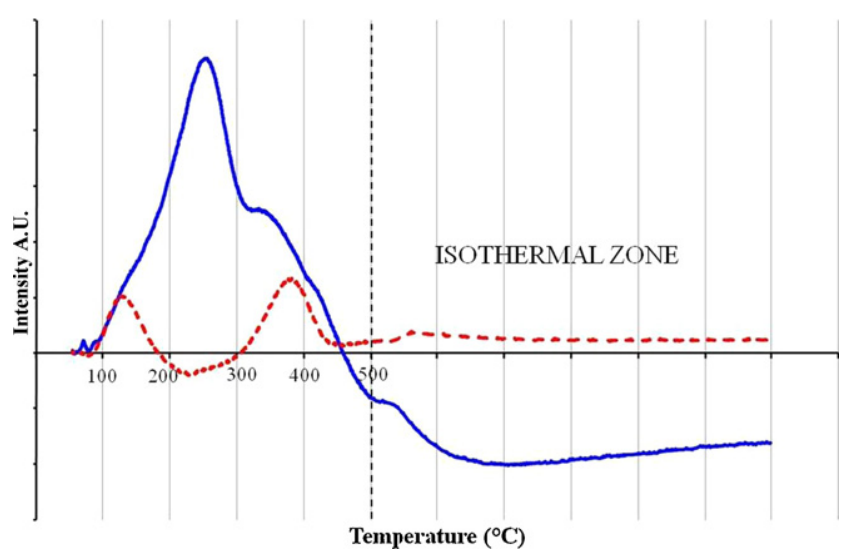

Fig. 3. TPR of fresh Cat1 (dot line) and Cat3 (full line).

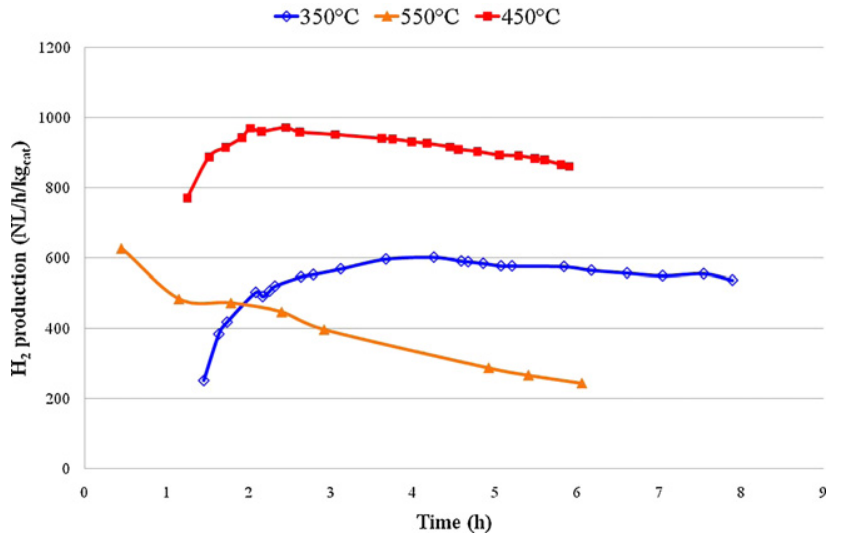

Fig. 4. $\mathrm{H}_{2}$ productivity versus time at different temperatures for Cat2: $350{ }^{\circ} \mathrm{C}$ $(\diamond) ; 450^{\circ} \mathrm{C}(\mathbf{\square}) ; 550^{\circ} \mathrm{C}(\mathbf{\Delta})$ (reaction conditions: $0.5 \mathrm{MPa}$; JetA1 surrogate (JA1-S): $\mathrm{N}_{2}=10: 90(\mathrm{v} / \mathrm{v})$; contact time $\left.=2 \mathrm{~s}\right)$.

of two peaks, the first one attributable to the reduction of surface $\mathrm{Pt}^{\mathrm{IV}}$ to $\mathrm{Pt}^{0}$ and the second, at higher temperature, probably due to a core and shell effect $[20,22]$ or a strong interaction of the $\mathrm{Pt}$ with the support $[23,24]$. The addition of Sn significantly modify the reduction profile; Cat3 show a shoulder at low temperature again attributable to $\mathrm{Pt}^{\mathrm{IV}}$ reduction, with further three peaks at higher temperatures. The most intense first peak may be attributed to the presence Pt-containing species easier reducible in presence of $\mathrm{Sn}$, the second to the reduction of Pt/Sn alloys (also evidenced by XRD analysis) $[20,25,26]$ and, finally, the peak at higher temperature to the reduction of surface $\mathrm{SnO}_{2}$ to $\mathrm{Sn}^{\mathrm{II}}$ or to $\mathrm{Sn}^{0}$ [26].

\subsection{Catalytic tests}

Preliminary tests were performed on Cat2 $(\mathrm{Pt} / \mathrm{Sn}=1: 1, \mathrm{w} / \mathrm{w})$ to define the optimum temperature to maximize the $\mathrm{H}_{2}$ production (Fig. 4), feeding a $10 \%(\mathrm{v} / \mathrm{v})$ mixture of vaporised JA1-S diluted in $\mathrm{N}_{2}$. The activity strongly increases with the temperature up to $450^{\circ} \mathrm{C}$, while a further increase of temperature quickly decreases the $\mathrm{H}_{2}$ production, with a relevant catalyst deactivation. This behaviour may be correlated to the promotion by the high temperatures of side reactions, such as cracking and isomerisation, followed by catalyst surface coverage by coke. Thus, $450{ }^{\circ} \mathrm{C}$ may be considered a best compromise temperature for the reaction in terms of catalyst stability and $\mathrm{H}_{2}$ productivity; thus subsequent tests were performed at this temperature.

$\mathrm{H}_{2}$ for PEM fuel cells has to be very pure ( $\left.99.99 \%\right)$ and separation of $\mathrm{H}_{2}$ from nitrogen may be not simple; moreover, to reach a defined amount of $\mathrm{H}_{2}$, the volume of reactant fed to the reactor should be high, and thus, concentrated JA1-S feed appears most suitable. Fig. 5 shows the results of tests performed at $450^{\circ} \mathrm{C}$, feeding diluted and concentrated JA1-S. It is noteworthy that on increasing the feed concentration the $\mathrm{H}_{2}$ production increases by a factor 3-4, although the catalyst life with time-on-stream slightly decreases. Thus these results indicate that it is possible to work with pure JA1-S and obtaining encouraging $\mathrm{H}_{2}$ productivity per $\mathrm{L}$ of reactor.

The role of the active phase composition was investigated in reactions at $450{ }^{\circ} \mathrm{C}$, feeding pure JA1-S to axaminate the role of $\mathrm{Sn}$ in modulating the activity of $\mathrm{Pt}$ (Fig. 6). The Cat1 ( $\mathrm{Pt} / \mathrm{Al}_{2} \mathrm{O}_{3}$ ) catalyst has a high initial conversion, but deactivates quickly after few hours of time-on-stream, with a low overall $\mathrm{H}_{2}$ production. The addition of Sn produces significant increases of catalyst activity and stability; however, while of the deactivation rate is enhanced by increasing the Sn-content (Cat3), the activity worsens moving from $1 \mathrm{wt} . \%$ of $\mathrm{Sn}$ (Cat2) to $3 \mathrm{wt} . \%$ (Cat3). The conversion values for the different 


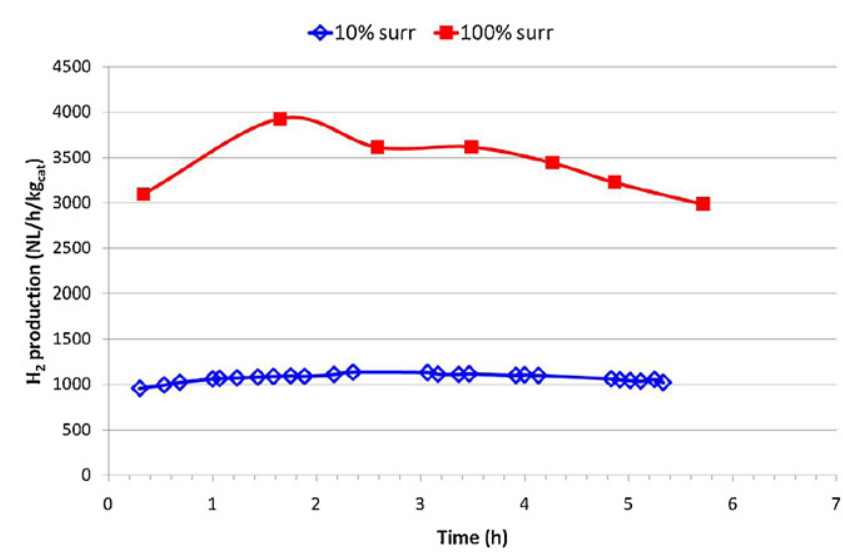

Fig. 5. $H_{2}$ productivity versus time for Cat2 feeding pure $(\boldsymbol{\square})$ or $\mathrm{N}_{2}$ diluted $(\diamond) \mathrm{JA} 1-\mathrm{S}$ (reaction conditions: $0.5 \mathrm{MPa}, 450^{\circ} \mathrm{C}$, contact time $=2 \mathrm{~s}$ ).

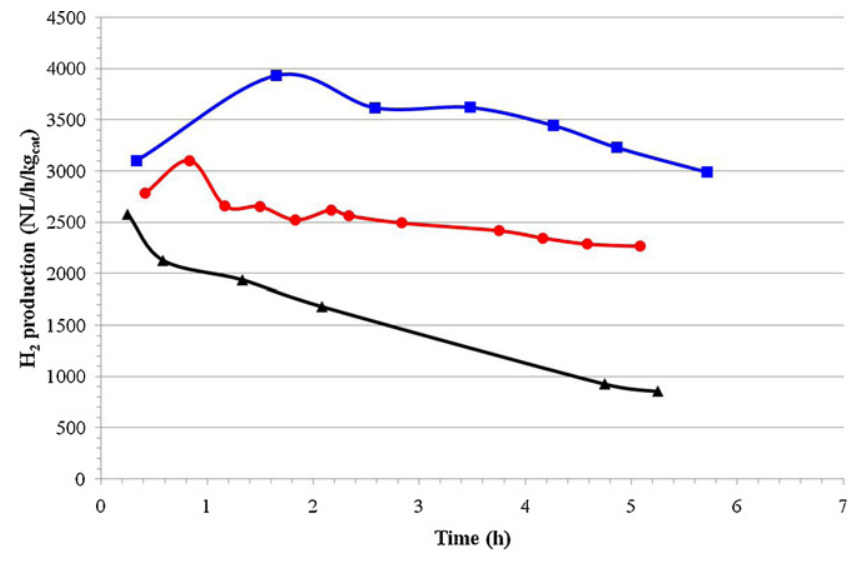

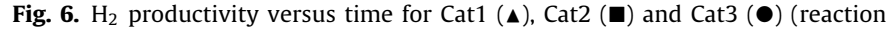
conditions: $0.5 \mathrm{MPa} ; 100 \% \mathrm{JAI}-\mathrm{S} ; 450^{\circ} \mathrm{C}$, contact time $=2 \mathrm{~s}$ ).

components of JA1-S (Fig. 7) reflect the $\mathrm{H}_{2}$ productivity, showing higher reactivities for the cyclic compounds (methylcyclohexane, decalin and tetralin), while ter-butylbenzene almost does not react regardless of reaction conditions and catalyst compositions.

On the basis of these results, Cat2 seems to be the best compromise between $\mathrm{H}_{2}$ productivity and stability with time-onstream. Although the specific application does not require very long catalyst-life time, nevertheless first results show a good stability for some hundreds hours with, furthermore, the possibility to regenerate catalyst. Anyway in this preliminary work, the attention was

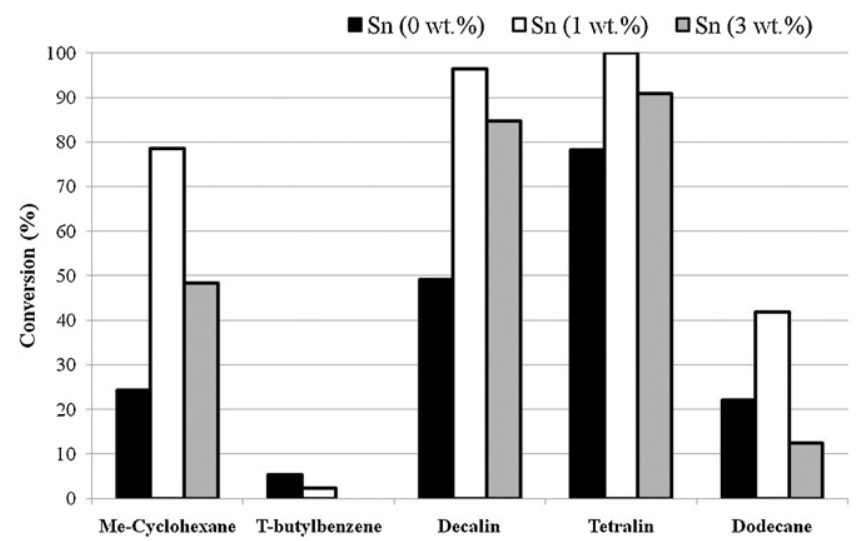

Fig. 7. Conversion values for the different components of JA1-S as a function of the Sn content (reaction conditions $0.5 \mathrm{MPa}, 100 \% \mathrm{JA} 1-\mathrm{S}, 450^{\circ} \mathrm{C}$; contact time $=2 \mathrm{~s}$ ).

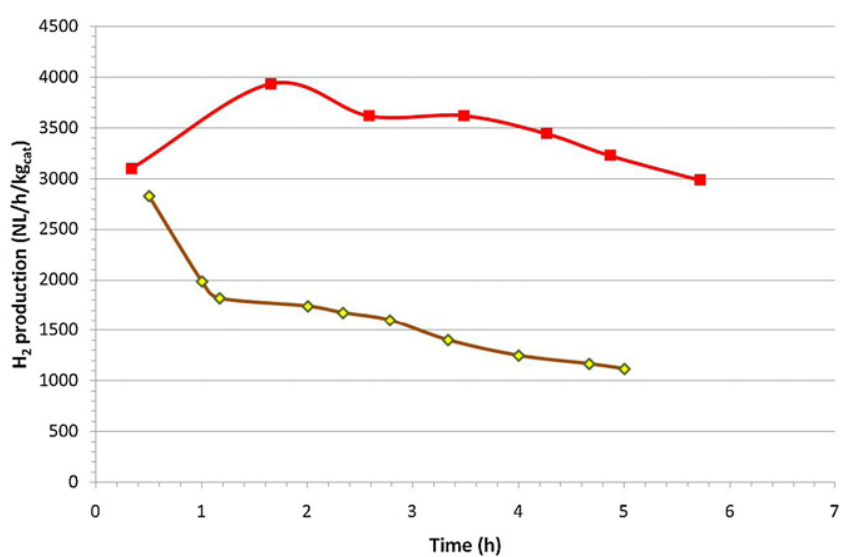

Fig. 8. H2 productivity versus time for Cat2 feeding S-free or $50 \mathrm{ppm}$ of S JA1-S (reaction conditions: $0.5 \mathrm{MPa} ; 100 \% \mathrm{JA} 1-\mathrm{S} ; 450{ }^{\circ} \mathrm{C}$; contact time $=2 \mathrm{~s}$ ).

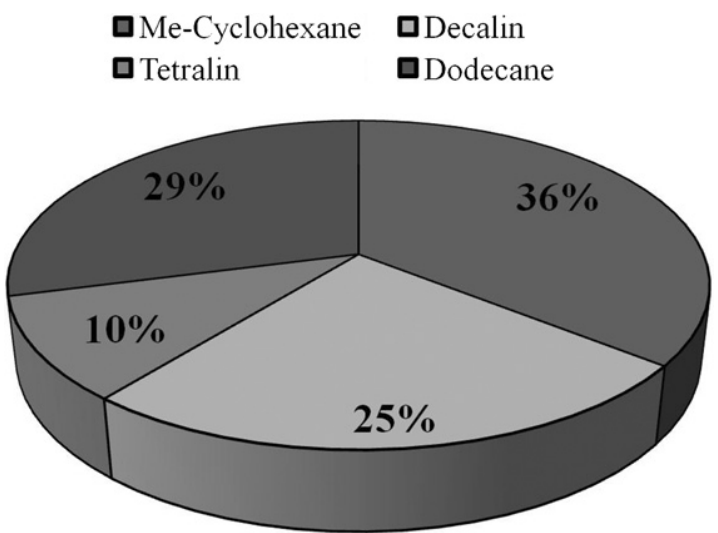

Fig. 9. Hydrogen productivity distribution as a function of the component present in the JA1-S (reaction conditions: Cat2; $0.5 \mathrm{MPa} ; 100 \% \mathrm{JA} 1-\mathrm{S} ; 450{ }^{\circ} \mathrm{C}$; contact time $=2 \mathrm{~s}$ ).

mainly focused on the role of reaction parameters and active phase composition on catalytic activity in order to verify the feasibility of the project. Its thio-tollerance was also investigated, considering that jet-fuels normally contain significant amounts of S-containing compounds, that may affect the activity of Pt. Fig. 8 provides a comparison between tests performed feeding JA1-S with and without $50 \mathrm{ppm}$ of sulfur. The results show a significant and rapid deactivation in presence of $S$, probably due to the formation of platinum sulfide [27]. Thus, these Pt-containing catalysts may be applied using sulfur-free jet fuel, already available on the market, or require further improvement to increase their thiotolerance.

\section{Conclusions}

Very encouraging $\mathrm{H}_{2}$ productivity values may be obtained in the partial dehydrogenation (PDh) of hydrocarbon blends, simulating jet fuel compositions, using a $(1: 1, \mathrm{w} / \mathrm{w}) \mathrm{Pt}-\mathrm{Sn} /$ alumina catalyst (Cat2) operating at $450^{\circ} \mathrm{C}$ and feeding the sulfur-free surrogate Jet A1 fuel. Although at this temperature the catalyst deactivation is somewhat faster, it represents a good compromise between activity and deactivation rate. The presence of Sn tailors the reactivity of Pt by the formation of different Pt-Sn alloys, increasing the activity and reducing the undesired side reactions. The composition and reactivity of these alloys depend on the Sn-content; however, all these catalysts deactivate significantly in presence of S-contents lower than those present in the currently employed jet fuels. Cat2 shows a $\mathrm{H}_{2}$ productivity of about $3000 \mathrm{NL} / \mathrm{kg}_{\text {cat }} / \mathrm{h}$, which is sufficient to produce $3 \mathrm{~kW}$ of electric power, considering purification steps and a fuel cell efficiency of $50 \%$; this result is encouraging for 
real applications on automotive or aviation transports. On the basis of JetA1-S composition and catalytic data it is possible to calculate the contribution of the different compounds to this $\mathrm{H}_{2}$ productivity value (Fig. 9).

\section{Acknowledgments}

Financial support by the EU - FP7 for the GreenAir project (FP7AAT-2008-RTD-1) - Grant Agreement No. 233862 - is gratefully acknowledged.

\section{References}

[1] S.G. Chalk, J.F. Miller, J. Power Sources 159 (2006) 73-80.

[2] S. Satyapal, J. Petrovic, C. Read, G. Thomas, G. Ordaz, Catal. Today 120 (2007) $246-256$.

[3] H.L. Hellman, R. van den Hoed, Int. J. Hydrogen Energy 32 (2007) 305-315.

[4] R.B. Biniwale, S. Rayalu, S. Devotta, M. Ichikawa, Int. J. Hydrogen Energy 33 (2008) $360-365$.

[5] C.L. Aardahl, S.D. Rassat, Int. J. Hydrogen Energy 34 (2009) 6676-6683.

[6] Y. Okada, E. Sasaki, E. Watanabe, S. Hyodo, H. Nishijima, Int. J. Hydrogen Energy 31 (2006) 1348-1356.

[7] Y. Saito, K. Aramaki, S. Hodoshima, M. Saito, A. Shono, J. Kuwano, K. Otake, Chem. Eng. Sci. 63 (2008) 4935-4941.

[8] M.P. Lazaro, E. Garcia-Bordejé, D. Sebastian, M.J. Lazaro, R. Moliner, Catal. Today 138 (2008) 203-209.
[9] M.R. Rahimpour, Int. J. Hydrogen Energy 34 (2009) 2235-2251.

[10] B. Wang, G.F. Froment, D. Wayne Goodman, J. Catal. 253 (2008) 239-243.

[11] N. Kariya, A. Fukuoka, T. Utagawa, M. Sakuramoto, Y. Goto, M. Ichikawa, Appl. Catal. A 247 (2003) 247-259.

[12] S. Hodoshima, N. Hiroaki, S. Yasukazu, Appl. Catal. A 292 (2005) 90-96.

[13] R.B. Biniwale, N. Kariya, M. Ichikawa, Catal. Lett. 105 (2005) 83-87.

[14] Y. Wang, N. Shah, F.E. Huggins, G.P. Huffman, Energy \& Fuels 20 (2006) $2612-2615$.

[15] S. Yolcular, O. Olgun, Catal. Today 138 (2008) 198-202.

[16] D. Sebastian, E.G. Bordejé, L. Calvillo, M.J. Lazaro, R. Moliner, Int. J. Hydrogen Energy 33 (2008) 1329-1334.

[17] K. Akamatsu, Y. Ohta, T. Sugawara, T. Hattori, S. Nakao, Ind. Eng. Chem. Res. 47 (2008) 9842-9847.

[18] P. Dung Tien, T. Satoh, M. Miura, M. Nomura, Fuel Process. Technol. 89 (2008) 415-418.

[19] P. Li, Y. Huang, D. Chen, J. Zhu, T. Zhao, X. Zhou, Catal. Commun. 10 (2009) 815-818.

[20] H. Lieske, J. Völter, J. Catal. 90 (1984) 96-105.

[21] F. Tuinstra, J.L. Koenig, J. Chem. Phys. 53 (3) (1970) 1126-1130.

[22] J.M. Badano, M. Quiroga, C. Betti, C. Vera, S. Canavese, F. Colma-Pascual, Catal. Lett. $137(1-2)(2010) 35-44$.

[23] H. Lieske, G. Lietz, H. Spindler, J. Voelter, J. Catal. 81 (8) (1983).

[24] T. Huizinga, J. van Grondelle, R. Prins, Appl. Catal. 10 (1984) 199-213.

[25] S.A. Bocanegra, S.R. de Miguel, I. Borbath, J.L. Margitflavi, O.A. Scleza, J. Mol. Catal. A 301 (2009) 52-60.

[26] A.D. Ballarini, P. Zgolicz, I.M.J. Vilella, S.R. de Miguel, A.A. Castro, O.A. Scleza, Appl. Catal. 381 (1-2) (2010) 83-91.

[27] S. Albertazzi, G. Busca, E. Finocchio, R. Glöckler, A. Vaccari, J. Catal. 223 (2004) 372-381. 